\title{
Design and Implementation of an Active Clamped Full Wave Quasi Resonant ZCS Boost Converter
}

\author{
M.Venmathi, D.Indira
}

\begin{abstract}
This paper presents a closed loop control of an active-clamped full-wave quasi-resonant boost converter with zero-current-switching (ZCS) for power factor correction. Possibility to incorporate higherswitching frequency and has some potency to reduce switching losses. Power factor improvement and high efficiency is achieved with a constant output voltage and DC output voltage is regulated by using closed loop control.The concept of the proposed switchingscheme results lesser switching loss, higher efficiency, possibility to have higher switching frequency, and has potential to reduce converter's conducted EMI. This paper also presents voltage regulation using closed loop system and the simulation results are verified.
\end{abstract}

Index Terms:Quasi ResonantBoost converter, Zerocurrent switching (ZCS), Half Bridge Rectifier, Resonant circuit, Power factor Correction.

\section{INTRODUCTION}

Soft switching technique is one of the most effective solutions to reduce the switching loss in high-frequency operations, which is an approach made by researches and engineers in the field of power electronics circuits and systems [1]-[2]. Various types of soft switching circuits have been proposed and applied to power converters operated at a high switching frequency, leading to a great reduction of the switching loss as well as mitigation of electromagnetic noise.

On the other hand, introducing power devices with a low on state voltage/resistance is the only way to reduce the on-state losses. Super junction structures make it possible to decrease the on-state voltage and/or resistance drastically, which has been introduced to MOSFETs and IGBTs [3]-[4].

Generally, MOSFETs using a super junction structure have a relatively large input/output capacitance $C_{\mathrm{i}}$ and $C_{\mathrm{o}}$ and a large reverse recovery charge $Q_{\mathrm{rr}}$ in the source to drain reverse diode characteristics [5]. Switching losses caused by $C_{\mathrm{o}}$ and $Q_{\mathrm{rr}}$ can be minimized by applying the soft switching techniques to the converter circuit. However, the large input capacitance $C_{\mathrm{i}}$ results in a great increase of the power consumption in the gate-drive circuit especially at a high frequency operation.

To improve power factor using boost converters between the rectifier bridge and the DC bus capacitor has been proposed [6-8]. One difficulty of this technique is the

Revised Manuscript Received on July 22, 2019.

Dr.M.Venmathi, Associate Professor, Departmentof Electrical and Electronics Engineering, St. Joseph's College of Engineering, Chennai, India.

D.Indira, Research Scholar, Department of Electrical and Electronics Engineering, St. Joseph's College of Engineering, Chennai, India. switching losses, which limit the maximum switching frequency of the converter. To overcome this disadvantage, resonant converters have been proposed, to replace the hard-switching boost converter presents half-wave zero-current-switch quasi-resonant (ZCS-QR) based PFC as an alternative to the above mentioned boost-based circuit [9-11]. Realization of ZCS-QR to a PFC circuit makes the application of higher switching frequency more feasible. This technique is claimed to generate less EMI due to:

1) Reduce the excitation of the parasitic elements [12]

2) Inherently apply frequency modulation scheme that may further reduce the noise level $[13,14]$.

To improve the efficiency of the power factor correction rectifier, much effort has been made on the soft-switching rectifier [15-23]. Instead of half-wave, [24] use the full-wave ZCS-QR topology in its PFC and this topology was selected for its consistent timing consideration. This makes the converter control effort less demanding [25-27].

\section{RESONANT BOOST CONVERTER}

The Conventional Active Clamped ZCS Quasi Resonant Boost Converter is shown in Fig.1. Voltage ringing problem can be alleviated by the clamp diode referred from [19]. This problem normally occurred in a full-wave ZCS-QR boost circuit during main switch $\mathrm{S}$ turn-off period.

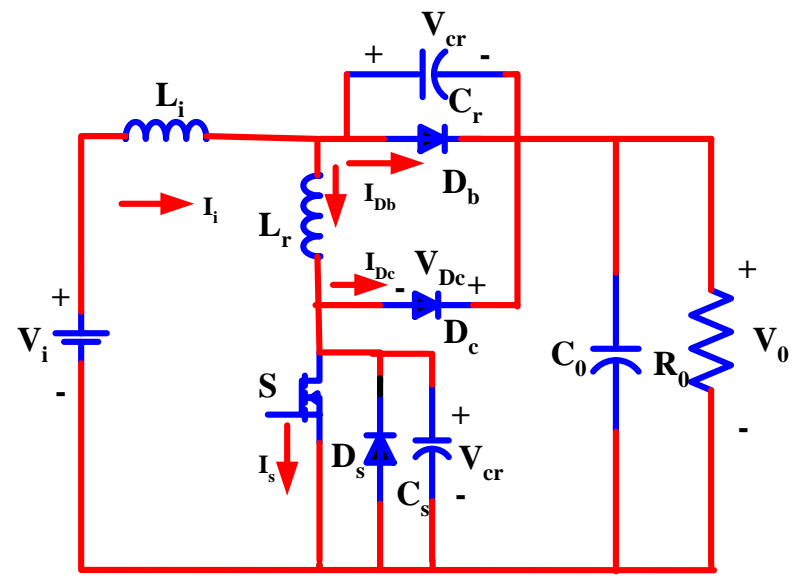

Fig.1 Resonant Boost Converter

Also, $D_{c}$ slightly changes the operating condition of the ZCS-QR switch .The Fig.1 reveal that: (a) high reverse recovery current occurs on diode $\mathrm{D}_{\mathrm{c}}$ and (b) Current flowing through $\mathrm{L}_{\mathrm{r}}$ is non-zero during switch turn-on transition. Those problems result in higher losses and more EMI emission. The modified circuit is shown in Fig.2.

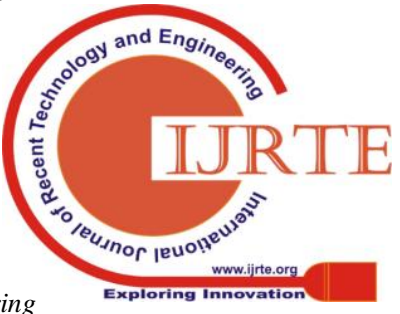




\section{Design and Implementation of an Active Clamped Full Wave Quasi Resonant ZCS Boost Converter}

\section{MODIFIED ACTIVE CLAMPED FULL WAVE ZCS-QR BOOST CONVERTER}

The Modified Active Clamped Full wave ZCS-QR Boost Converter is shown in Fig.2. It uses an active-clamp Full bridge scheme to solve the abovementioned problems [25]. In this paper, the circuit of [20] is used as base of the proposed PFC. This circuit consists of rectifier, active clamp ZCS resonant boost converter and a load.

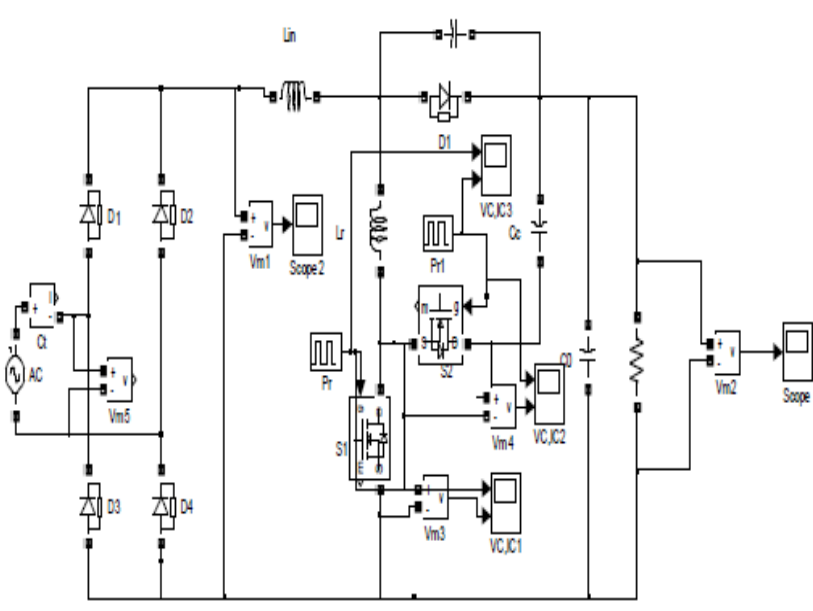

Fig.2. Modified Active Clamped Full wave ZCS-QR Boost Converter

The rectifier circuit will convert the ac input into DC which is given to active clamp boost converter as input. An active clamp MOSFET in the circuit of [25] alleviate the voltage ringing problem and the DC output from the rectifier is increased by boost converter. Reference [26] gives detailed expression regarding full wave ZCS-QR circuit operations. In that reference, all equations are normalized to three resonant tank parameters as follows:

Resonant Frequency:

$$
\begin{gathered}
f_{r}=\frac{1}{2 \prod \sqrt{L_{r} C_{r}}} \\
\omega_{0}=\theta
\end{gathered}
$$

Characteristic Impedance:

$$
\begin{aligned}
& Z_{0}=\sqrt{\frac{L_{r}}{C_{r}}} \\
& J_{S}=I_{i} \frac{R_{0}}{V_{0}}
\end{aligned}
$$

Voltage Conversion Ratio:

$$
M=\frac{V_{0}}{V_{i}}
$$

Normalized Switching Frequency

$$
\gamma=\frac{f_{s}}{f_{r}}
$$

The concept of power factor in case of sinusoidal voltages and current, relates to the real power, reactive power, and apparent power associated with the load consisting of resistance and reactance bringing about a direct phase shift between the voltage and current.

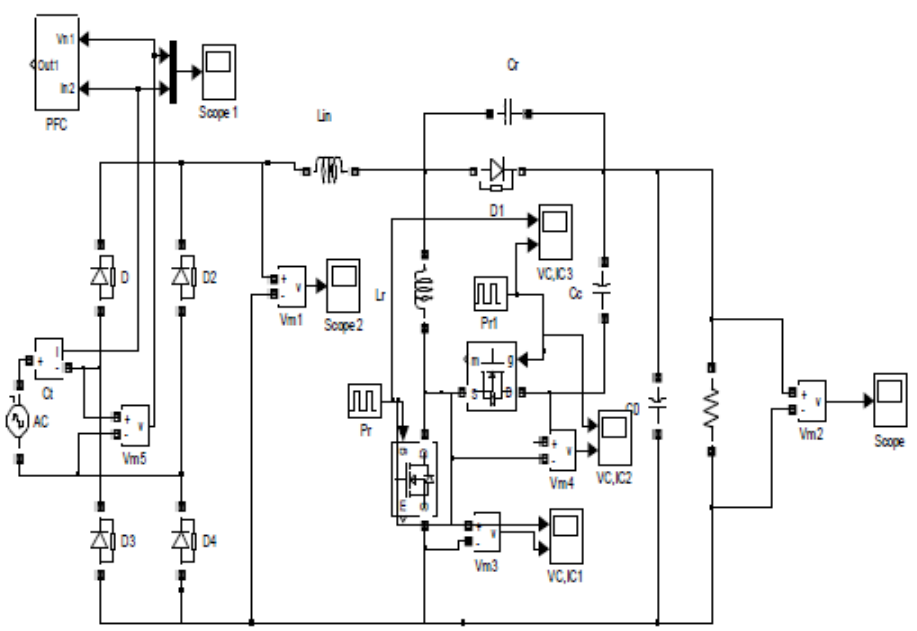

Fig.3. Power Factor Correction of Modified Active clamped Full wave ZCS-QR Boost Converter

When the load is the combination of resistive and reactive elements then the power factor will vary from 0 to 1 . If the current leads the voltage across the load, the load has a leading power factor. If the current lags the voltage across the load, the load has a lagging power factor.

Power factor can be an important aspect to consider in an Ac circuit, because any power factor less than 1 means that the circuits wiring has to carry more current than what would be necessary with zero reactance in the circuit to deliver the same amount of (true) power to the resistive load.

\section{CLOSED LOOP OPERATION}

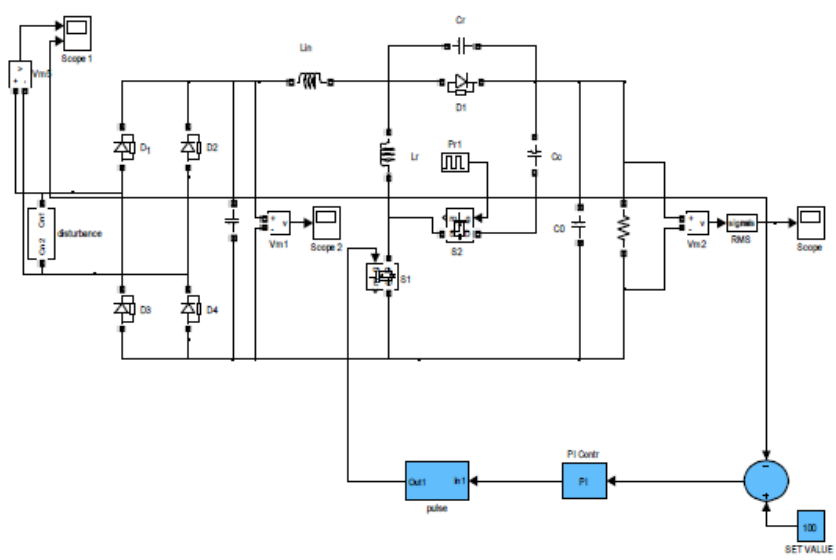

Fig.4. Closed Loop Configuration

As all the DC-DC converters, Boost converters are designed to work in open-loop mode. However, these kinds of converters are nonlinear. This non-linearity is due to the switch and the

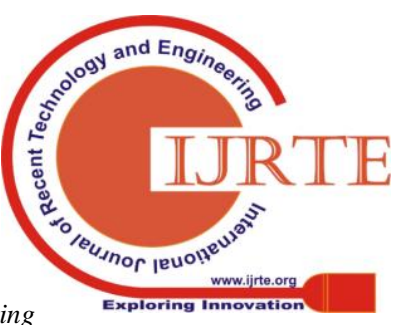
\& Sciences Publication 
converter component characteristics. For some applications, the Boost converters must provide a regulated output voltage with low ripple rate. In addition, the converter must be robust against load or input voltage variations and converter parametric uncertainties. Thus, for such case the regulation of the output voltage must be performed in a closed loop control mode. For this purpose, PI-type controllers are proposed [27].

\section{SIMULATION RESULTS}

The active clamped full wave ZCS Quasi Resonant Boost converter is simulated using Matlab and the results are presented. The DC input voltage is $100 \mathrm{~V}$. The triggering pulse for switch $S_{1}$ and $S_{2}$ are shown in Fig.5 and Fig.6.The DC output voltage is shown in Fig.7.

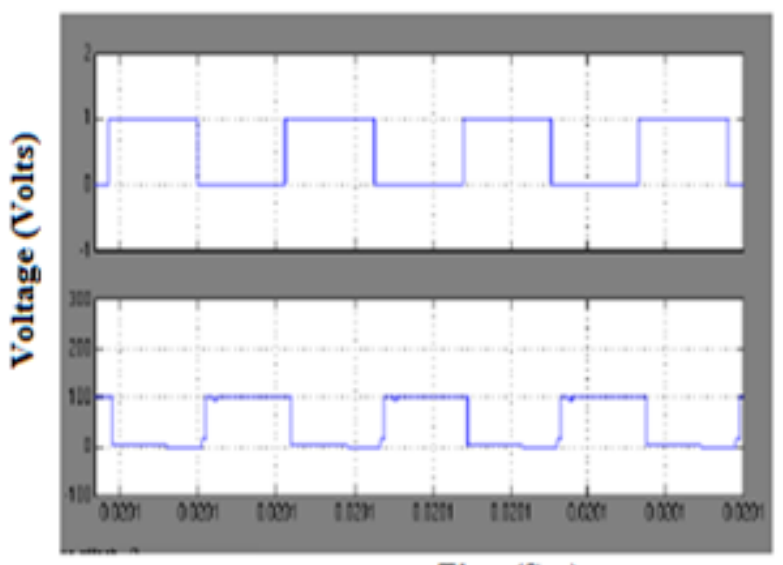

Time (Sec)

Fig.5.Triggering pulse and voltage across Switch $S_{1}$

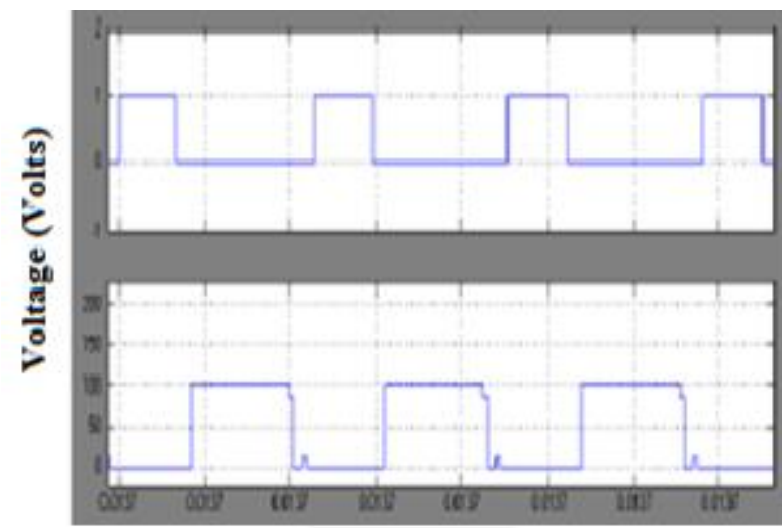

Time (Sec)

Fig.6 .Triggering pulse and voltage across Switch $\mathrm{S}_{2}$

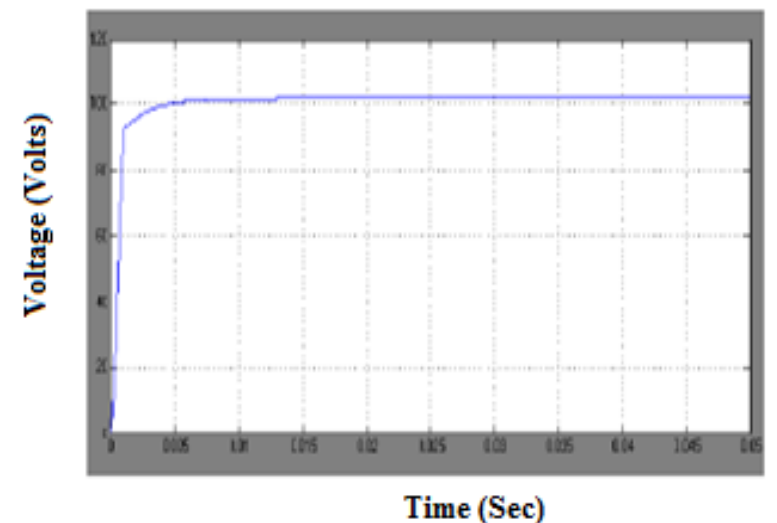

Fig.7. DC output voltage of Modified Active Clamped Full wave ZCS-QR Boost Converter
Its value is $106 \mathrm{~V}$. From the results it is clear that the output voltage is ripple free. Fig.8 shows the Input Voltage and Current and Power factor value is found to be nearly Unity. From the results, it is found that the output varies linearly with input voltage.

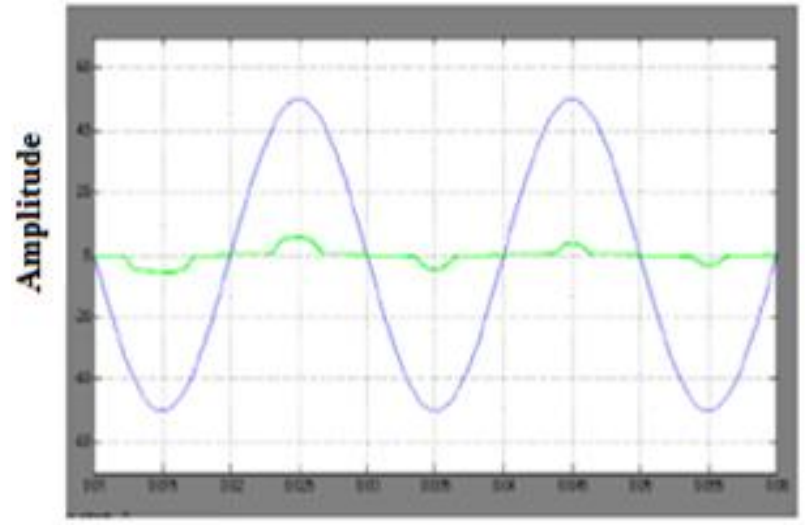

Time (Sec)

Fig.8. AC input voltage and current wave form.

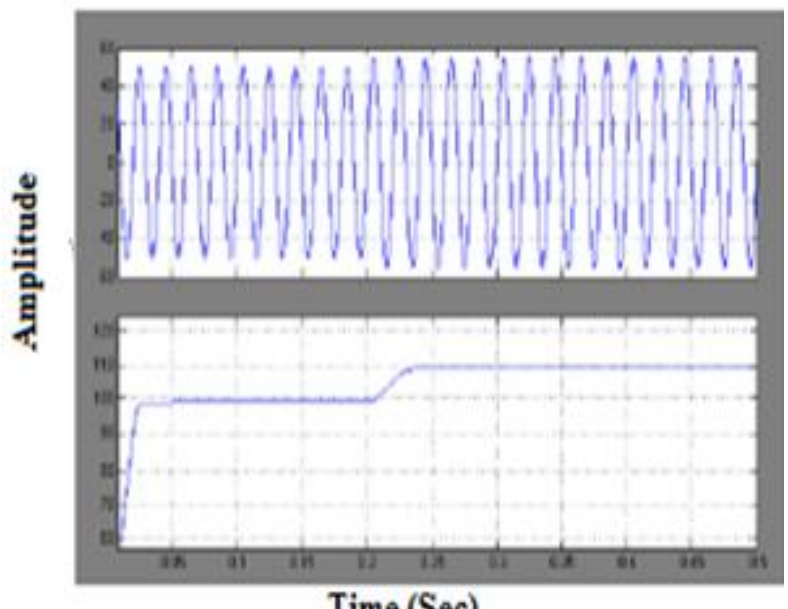

Time (Sec)

Fig.9. Open loop Performance

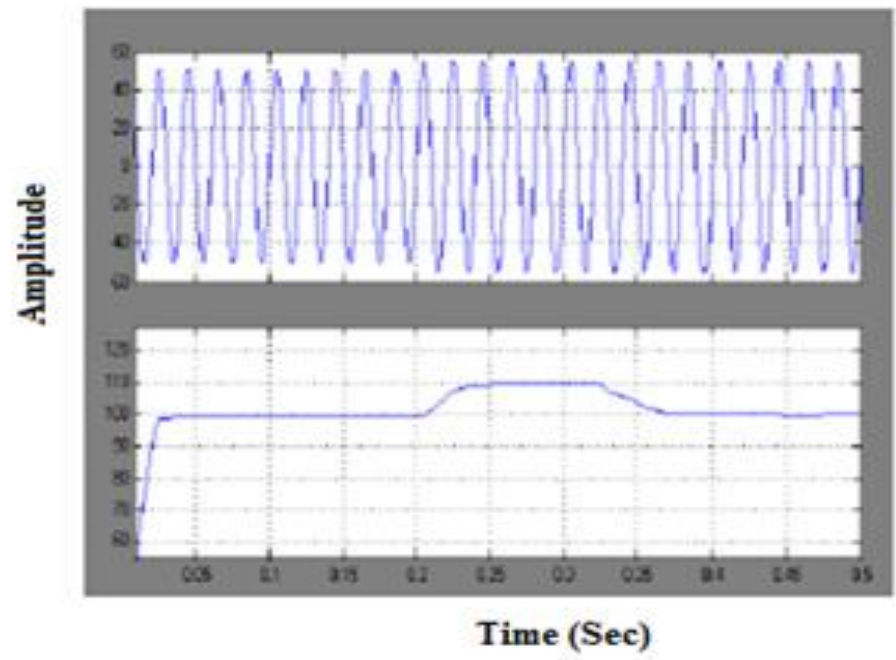

Fig.10 Closed Loop Performance

Fig 9. Shows the input voltage and output voltage for the open loop system. The disturbance is applied at 0.2 seconds. For open-loop system we observe that open-loop system has steady state error. The input voltage is increased to $110 \mathrm{~V}$ by introducing an

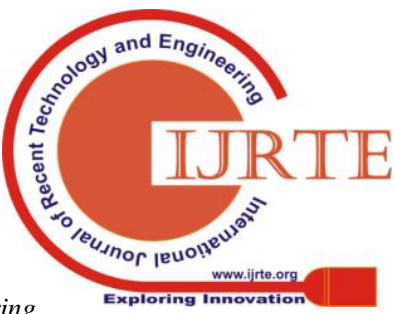

Engineering \& Sciences Publication 


\section{Design and Implementation of an Active Clamped Full Wave Quasi Resonant ZCS Boost Converter}

error signal at the input source. Correspondingly output voltage also increases from its set value of 100 .

The input voltage and output voltage waveform for the closed loop performance is shown in fig. 10. The disturbance is applied at $0.2 \mathrm{sec}$. From the above diagram, when theinput voltage is $50 \mathrm{~V}$, the output is boosted to $100 \mathrm{~V}$.If any disturbance in the input will cause change in the output voltage too. But the closed loop system regulates the output voltage to the same voltage level $100 \mathrm{~V}$.

\section{HARDWARE RESULTS}

The hardware is implemented with the following components

1. Microcontroller

2. Voltage Regulators

a. $\quad 7812$ voltage regulator

b. $\quad 7805$ voltage regulator

3. IC IR2110 for the amplification of the pulses given by Microcontroller

Fig. 11 shows the photograph of thehardware set up developed based on a digital PWM usingmicrocontroller.

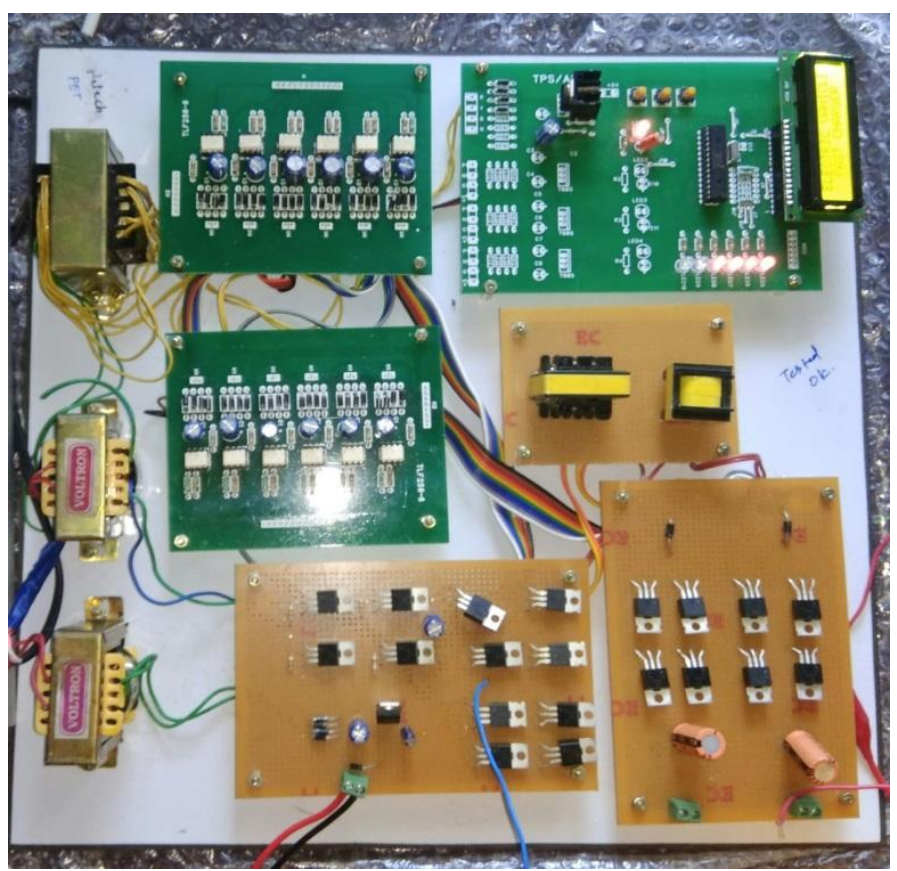

Fig.11 Photograph of experimental set-up

- A step-down transformer (230/15) V is used to give input supply to the power circuit.

- The $15 \mathrm{~V}$ AC input is rectified into $15 \mathrm{~V}$ pulsating DC with the help of full bridge rectifier circuit.

- The ripples in the pulsating DC are removed and pure DC is obtained by using a capacitor filter.
- The positive terminal of the capacitor is connected to the input pin of the 7812 regulator for voltage regulation.

- An output voltage of $12 \mathrm{~V}$ obtained from the output pin of 7812 is fed as the supply to the pulse amplifier.

- An output voltage of $5 \mathrm{~V}$ obtained from the output pin of 7805 is fed as the supply to the micro controller.

- From the same output pin of the 7805, a LED is connected in series with the resistor to indicate that the power is $\mathrm{ON}$.

\section{Power Supply Circuit:}

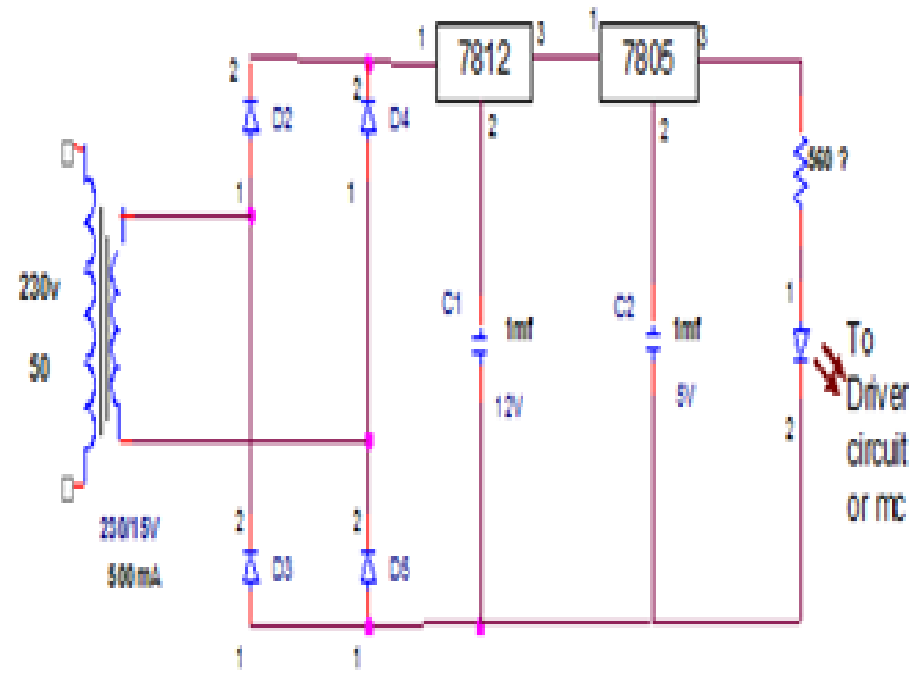

Fig.12 Power Supply Circuit

Hardware Power Circuit:

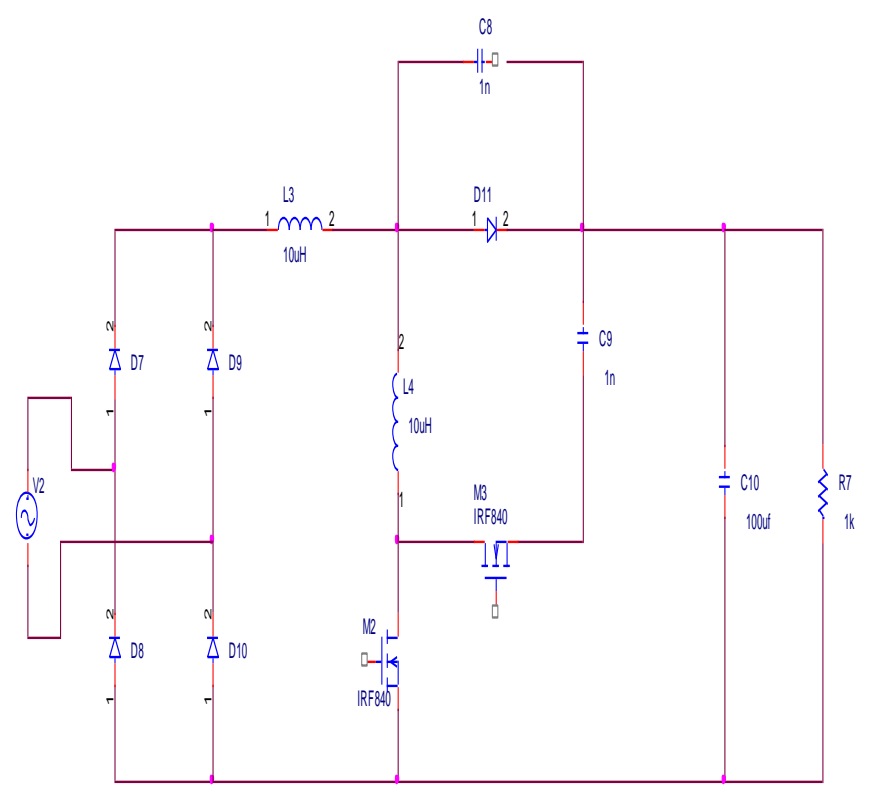

Fig.13 Hardware Power Circuit

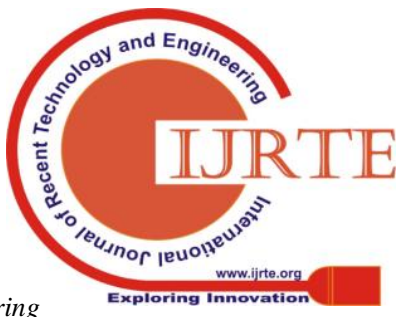


International Journal of Recent Technology and Engineering (IJRTE)

ISSN: 2277 - 3878, Volume-8, Issue-2S5, July 2019

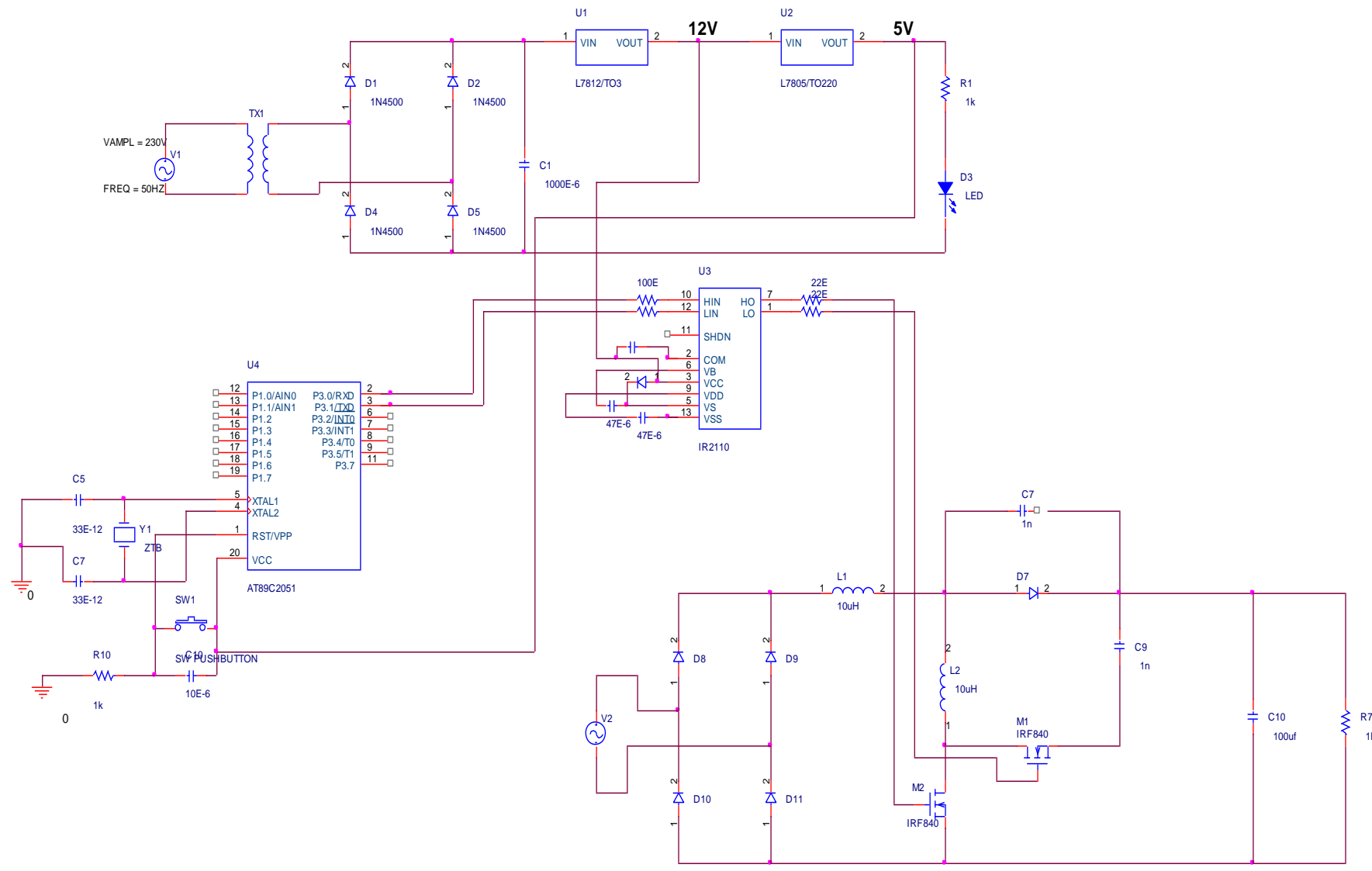

Fig.14Hardware Implementation for Active clamped quasi resonant boost converter

\begin{tabular}{|c|c|c|c|}
\hline & MPC & ENT & S USED: \\
\hline 1 & & $\mathrm{C} 1$ & $1000 \mathrm{E}-6$ \\
\hline 2 & 3 & $\mathrm{C} 2$ & 47E-6 \\
\hline & & C3 & $47 \mathrm{E}-6$ \\
\hline & & $\mathrm{C} 4$ & $47 \mathrm{E}-6$ \\
\hline 3 & 2 & $\mathrm{C} 5$ & $33 \mathrm{E}-12$ \\
\hline & & C6 & $33 E-12$ \\
\hline 4 & 2 & C7 & 1n \\
\hline & & C9 & 1n \\
\hline 5 & 1 & $\mathrm{C} 8$ & $10 \mathrm{E}-6$ \\
\hline 6 & 1 & $\mathrm{C} 1 \mathrm{C}$ & 100uf \\
\hline 7 & 10 & D1 & $1 \mathrm{~N} 4500$ \\
\hline & & D2 & $1 \mathrm{~N} 4500$ \\
\hline & & D4 & $1 \mathrm{~N} 4500$ \\
\hline & & D5 & $1 \mathrm{~N} 4500$ \\
\hline & & D6 & $1 \mathrm{~N} 4500$ \\
\hline & & D7 & $1 \mathrm{~N} 4500$ \\
\hline & & D8 & $1 \mathrm{~N} 4500$ \\
\hline & & D9 & $1 \mathrm{~N} 4500$ \\
\hline & & D1C & $1 \mathrm{~N} 4500$ \\
\hline
\end{tabular}

\begin{tabular}{|c|c|c|c|}
\hline & & D11 & $1 \mathrm{~N} 4500$ \\
\hline 8 & 1 & D3 & LED \\
\hline \multirow[t]{2}{*}{9} & 2 & $\mathrm{~L} 2$ & $10 \mathrm{uH}$ \\
\hline & & L1 & $10 \mathrm{uH}$ \\
\hline \multirow[t]{2}{*}{10} & 2 & M2 & IRF840 \\
\hline & & M1 & IRF840 \\
\hline \multirow[t]{3}{*}{11} & 3 & $\mathrm{R} 1$ & $1 \mathrm{k}$ \\
\hline & & R6 & $1 \mathrm{k}$ \\
\hline & & $\mathrm{R} 7$ & $1 \mathrm{k}$ \\
\hline 12 & 1 & $\mathrm{R} 2$ & $100 \mathrm{E}$ \\
\hline \multirow[t]{3}{*}{13} & 3 & R3 & $22 \mathrm{E}$ \\
\hline & & $\mathrm{R} 4$ & $22 \mathrm{E}$ \\
\hline & & R5 & $22 \mathrm{E}$ \\
\hline 14 & 1 & SW & 1SW PUSHBUTTON \\
\hline 15 & 1 & $\mathrm{U} 1$ & L7812/TO3 \\
\hline 16 & 1 & $\mathrm{U} 2$ & L7805/TO220 \\
\hline 17 & 1 & U3 & IR2110 \\
\hline 18 & 1 & $\mathrm{U} 4$ & PIC16F84 \\
\hline 19 & 1 & Y1 & ZTB \\
\hline
\end{tabular}




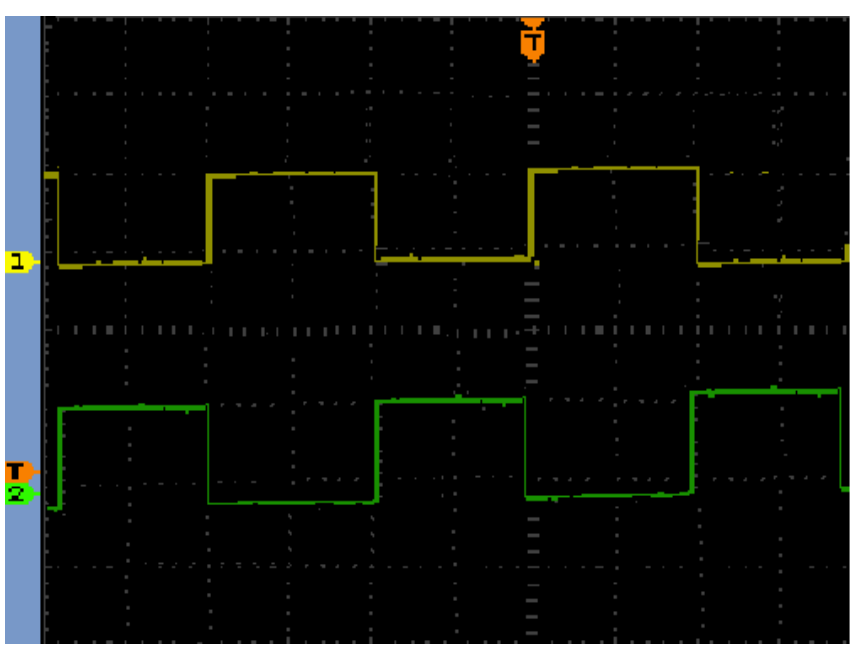

Fig.15Triggering pulse $(\mathrm{X}$ axis $=2 \mathrm{~ms} / \mathrm{div}, \mathrm{Y}$ axis $=1 \mathrm{~V} / \mathrm{div}$ ) and voltage across Switch $\mathrm{S}_{1}(\mathrm{X}$ axis $=2 \mathrm{~ms} / \mathrm{div}, \mathrm{Y}$ axis $=100 \mathrm{~V} / \mathrm{div}$ )

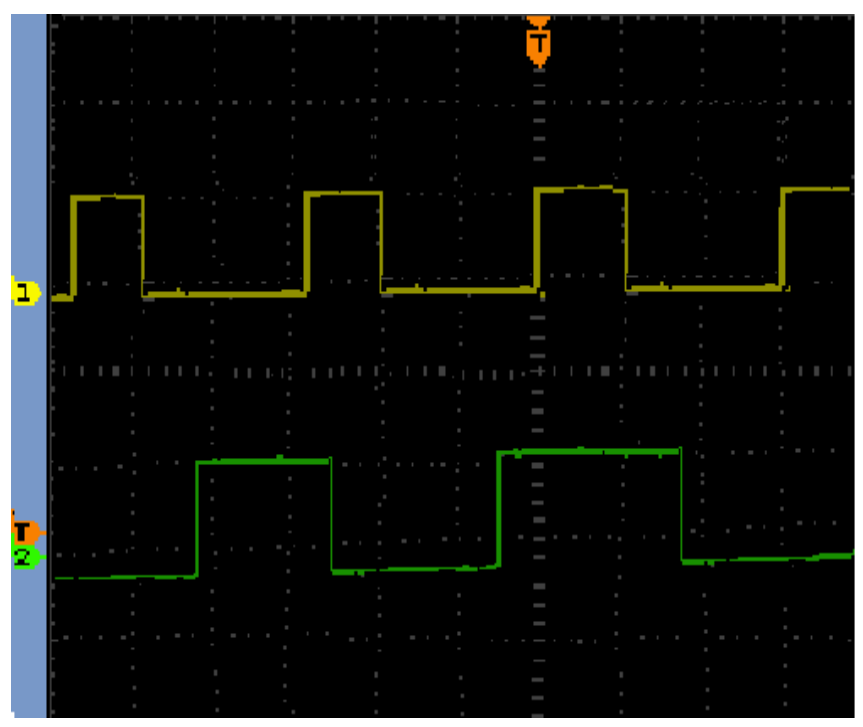

Fig.16 Triggering pulse $(\mathrm{X}$ axis $=2 \mathrm{~ms} / \mathrm{div}, \mathrm{Y}$ axis $=1 \mathrm{~V} / \mathrm{div}$ ) and voltage across Switch $\mathrm{S}_{2}(\mathrm{X}$ axis $=2 \mathrm{~ms} / \mathrm{div}, \mathrm{Y}$ axis $=100 \mathrm{~V} / \mathrm{div}$ )

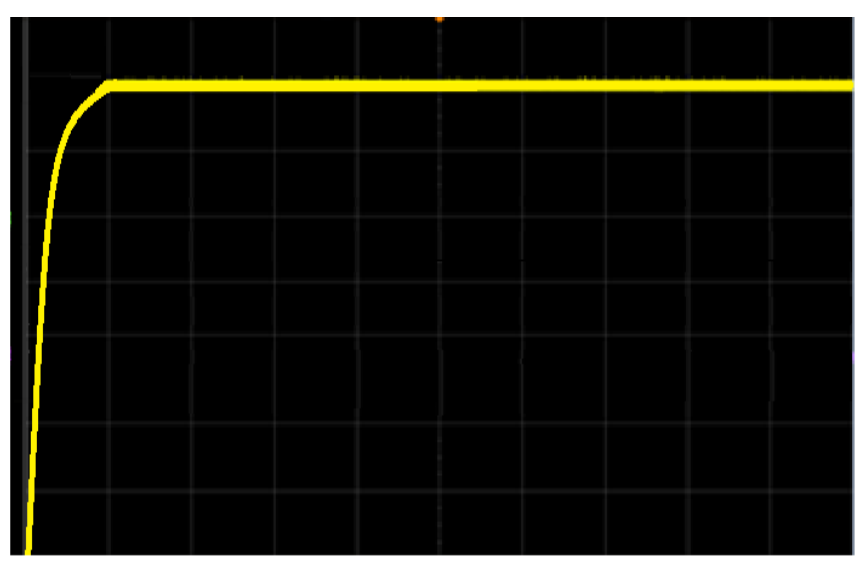

Fig.17DC output voltage of Modified Active Clamped Full wave ZCS-QR Boost Converter $(\mathrm{X}$ axis $=0.05 \mathrm{~s} / \mathrm{div}, \mathrm{Y}$ axis $=20 \mathrm{~V} / \mathrm{div}$ )

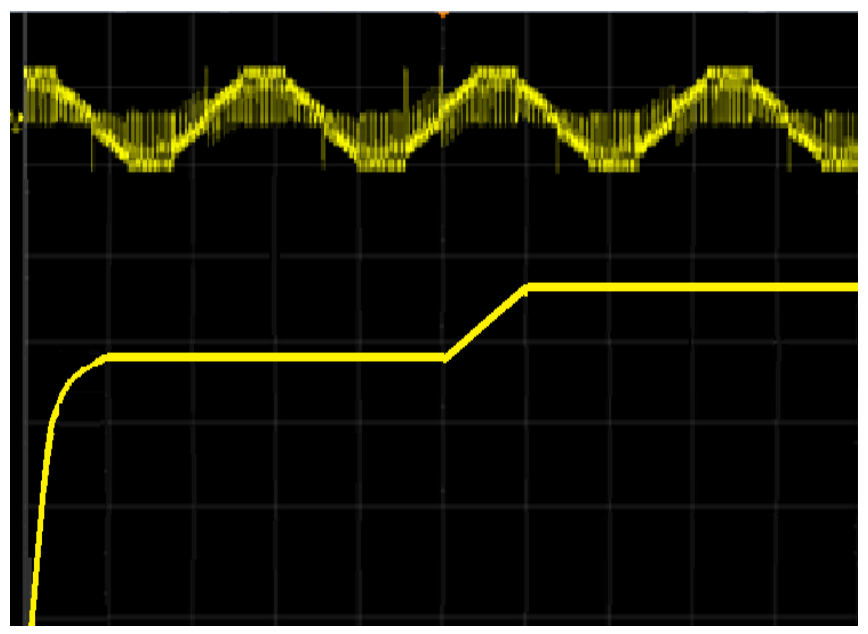

Fig.18Open loop Performance $((\mathrm{X}$ axis $=0.05 \mathrm{~s} / \mathrm{div}, \mathrm{Y}$ axis $=30 \mathrm{~V} / \mathrm{div}$ )

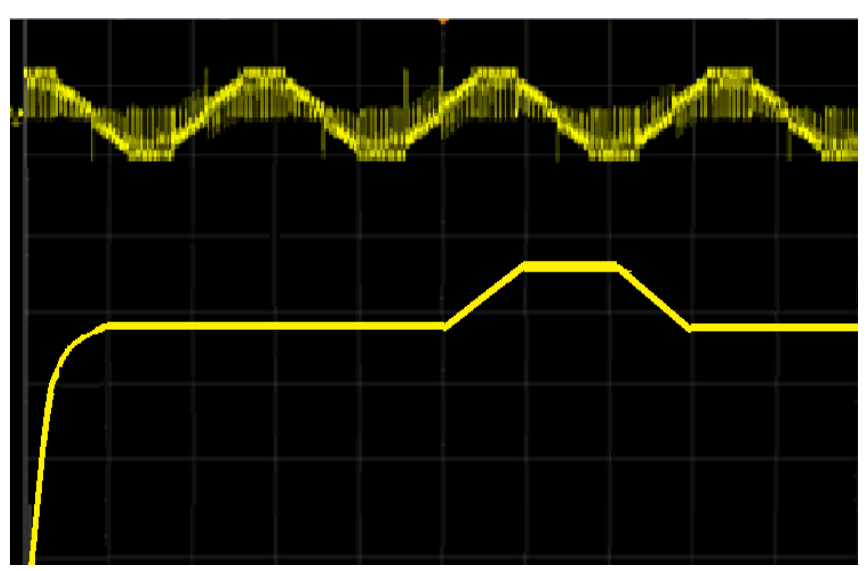

Fig.19Closed Loop Performance $((\mathrm{X}$ axis $=0.05 \mathrm{~s} / \mathrm{div}, \mathrm{Y}$ axis $=30 \mathrm{~V} / \mathrm{div}$ )

\section{CONCLUSION}

In this paper Closed loop control of an Active clamped full wave ZCS Quasi resonant Boost converter has been proposed.Power factor correction and high efficiency is achieved with constant output Voltage. DC output voltage is regulated by using closed loop control.This proposed circuit has proven to be able to alleviate the voltage ringing phenomena during switch turn-off period on a full-wave ZCS-QR boost converter. Besides that, active clamp circuit also gives additional benefit by adding ZCS characteristic to current converter. It has been shown that this technique performance is better if compared to former simple diode clamp topology in terms of efficiency, voltage regulation, and conducted EMI characteristics. This topology offers power factor correction application.

\section{REFERENCES}

1. D. M. Divan, - The resonant dc link converter-A new concept in static power conversion, in Proc. Conf. Rec. IEEEIAS Annu. Meet., 1986, pp. 648-656.

2. J. Lai, R. W. Young, G. W. Ott, J. W. McKeever, and F. Z. Peng, -A delta-configured auxiliary resonant snubber inverter, IEEE Trans. Ind. Appl., vol. 32, no. 3, pp. 518-525, May/Jun.1996.

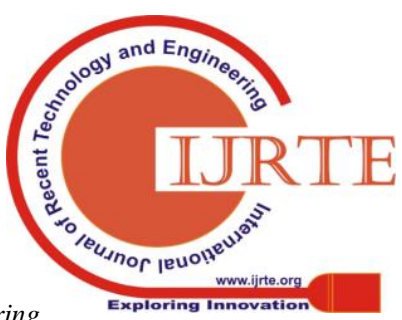
\& Sciences Publication 
3. J. S. Lai, B. M. Song, R. Zhou, A. Hefner, D.W. Berning, and C. C. Shen, - Characteristics and utilization of a new class of low on-resistance MOS gated power device, IEEE Trans. Ind.Appl., vol. 37, no. 5, pp. 1282-1289, Sep./Oct. 2001.

4. Z. Liang, B. Lu, J. D. van Wyk, and F. C. Lee, -Integrated CoolMOS FET/SiC-diode module for high performance power switching, IEEE Trans. Power Electron., vol. 20, no. 3, pp. 679-686, May 2005.

5. Y. Ren, M. Xu, J. Zhou, and F. C. Lee, -Analytical loss model of power MOSFET,\|IEEE Trans. Power Electron., vol. 21, no. 2, pp. 310-319, Mar. 2006.

6. Ned Mohan; T.M. Underland, R.J. Ferraro,"Sinusoidal Line Current Rectification With a 1OOKHz B-Sit Step-Up Converter ", IEEE-Pesc Records, 1984, pp 92-98.

7. Kalyan K. Sen, Alexander E. Emanuel," Unity. Power Single Phase Power Conditioning 'I, IEEE Pesc Records, 1987, pp 516,524.

8. Kwang-Hwa Liu and Yung-Lin Lin, " Current Waveform Distortion in Power Factor Correction Circuits Employing Discontinuos-Mode Boost Converters ' I , IEEE-Pesc Record, 1989, pp-516-524.

9. Barbi, I., Oliveira da Silva, S.A., "Sinusoidal line current rectification at unity power factor withboost quasi-resonant converters," Applied Power Electronics Conference and Exposition, 1990 Conference Proceedings, 1990, 11-16 Mar 1990, Page(s):553 - 562.

10.Sebastian, J., Uceda, J., Cobos, J.A., and Gil, P., "Using zero-currentswitched quasiresonant converters as power factor preregulator," International Conference on Industrial Electronics, Control and Instrumentation Proceedings IECON 1991, 28 Oct.-1 Nov. 1991 Page(s):225 - 230 vol.1

11.Sebastian, J., Martinez, J.A., Alonso, J.M., and Cobos, J.A. "Voltagefollower control in zero-current-switched quasi-resonant power factor preregulators," IEEE Transactions on Power Electronics Volume 13, Is-sue 4, July 1998 Page(s): 727 - 738.

12. B.Mammano and B.Carsten, -Understanding and Optimizing Electromagnetic Compatibility in Switchmode Power Supplies, Unitrode Power Supply Design Seminar, SEM1500, 2002.

13. A.Santolaria, J. Balcells, D. Gonzalez, J. Gago, -Evaluation of Switching Frequency Modulation in EMI Emission Reduction applied to Power Converters, Industrial Electronics Society, 2003. IECON '03. The 29th Annual Conference of the IEEE, Vol.3, 2-6 Nov. 2003. Page(s):2306 - 2311

14. F. Lin, D.Y.Chen, - Reduction of Power Supply EMI Emission by Switching Frequency Modulation, Power Electronics, IEEE Transactions, Volume 9, Issue 1, Jan. 1994, Page(s):132 - 137

15. C.M., Duarte, C., and Barbi, I.: -A new ZVS-PWM activeclamping high power factor rectifier analysis design and experimentation. IEEE PESC Record, 1998, pp. 230-236

16. Costa, A.V., Treviso, C.H.G., and Freitas, L.C.: -A new ZCS-ZVSPWM boost converter with unity power factor operation. IEEE PESC Record, 1994, pp. 404-410

17.Xu, D.M., Yang, C.,Ma, L., Qiao, C., Qian, Z., and He, X.: -A novel single-phase active-clamped PFC converterll. IEEE APEC Record, 1997, pp. 266-271

18. Gataric, S., Boroyevich, D., and Lee, F.C.: - Soft-switched singleswitch three-phase rectifier with power factor correctionll. IEEE APEC Record, 1994, pp. 738-744

19. Canesin, C.A., and Barbi, I.: - A novel single-phase ZCS-PWM high power factor boost rectifierll. IEEE PESC Record, 1997 pp. 110-114

20. Wakabayashi, F.T., and Canesin, C.A.: -A new family of zero-currentswitching PWM converters and a novel HPF-ZCS-PWM boost rectifierl. IEEE PESC Record, 1999, pp. 609-611

21. Souza, A.F., and Barbi, I.: - A New ZVS-PWM unity power factor rectifier with reduced conduction lossesll, IEEE Trans. Power Electron., $1995,10,(6)$, pp. $746-752$
22. Souza, A.F., and Barbi, I.: - A new ZCS quasi-resonant unity power factor rectifier with reduced conduction lossesll. IEEE PESC Record, 1995, pp. 1171-1177

23.Chio, H.S., and Cho, B.H.: -Zero-current-switching (ZCS) power factor pre-regulator (PFP) with reduced conduction losses\|. IEEE PESC Record, 2002, pp. 962-967.

24. E. Firmansyah, S. Tomioka, S. Abe, M. Shoyama, T. Ninomiya, -Zero Current Switch-Quasi Resonant Boost Converter Performance in Power Factor Correction Application Proc. of APEC 2009, pp. 1165-1169.

25. Firmansyah, E., Tomioka, S., Abe, S., Shoyama, M., Ninomiya T., - Steady state characteristics of active-clamped full-wave zero-current switched quasi-resonant boost converters, IEEE 6th International 2009 Power Electronics and Motion Control Conference-IPEMC '09, 17-20 May 2009 Page(s):556 - 560.

26. R. W. Erickson, D. Maksimovic, "Chapter 20 : Soft Switching", in Fundamentals of Power Electronics, second edition, Massachusetts:KluwerAcademic Publishers, 2001.

27. R.D. Middlebrook and S. Cuk, -A General Unified Approach to Modelling Switching Power Stagesl, IEEE Power Electronics Specialists Conference Rec., pp. 18-34, 1976.

\section{AUTHORS PROFILE}

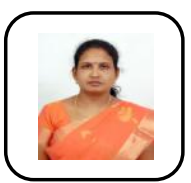

Dr. M. Venmathi is an Associate Professor in St. Joseph's College of Engineering, Chennai, Tamil Nadu, India. She obtained her Madras University, Chennai, India in 2003, ME in Power Systems Engineering from College of Engineering, Guindy, Anna University, Chennai, India in 2007. She obtained her PhD degree from Anna University in the area of solar PV systems interfacing converters. She has been working in the teaching field for about 12 years. She has published many papers in conferences journals. Her areas of interest include solar PV systems, power conversion techniques for renewable energy sources.

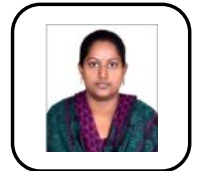

Indira Damarla is a Research Scholar in theDepartment of Electrical and Electronics Engineering at the St.Joseph's College of Engineering, Chennai, India. She received her B.Tech in EEE from Jawaharlal Nehru Technological University, Hyderabad, India in 2005, ME in Power Electronics and Industrial Drives from Sathyabama University, Chennai, India in 2011. She has ten years of teaching experience. She has a credit of publishing papers in an international conference and in journals.

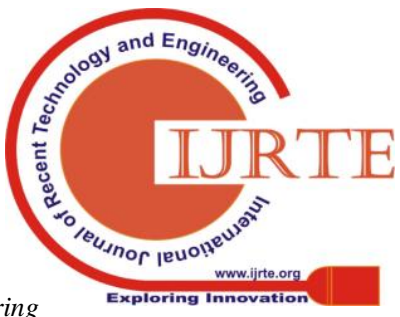

